\title{
Ending the Sri Lankan Civil War
}

\author{
Sumit Ganguly
}

Abstract: The Sri Lankan Civil War erupted in 1983 and dragged on until 2009. The origins of the conflict can be traced to Sri Lanka's colonial era and subsequent postcolonial policies that had significantly constrained the social and economic rights of the minority Tamil population. Convinced that political avenues for redressing extant grievances were unlikely to yield any meaningful results, a segment of the Tamil community turned to violence precipitating the civil war. A number of domestic, regional, and international efforts to bring about a peaceful solution to the conflict all proved to be futile. A military strategy, which involved extraordinary brutality on the part of the Sri Lankan armed forces, brought it to a close. However, few policy initiatives have been undertaken in its wake to address the underlying grievances of the Tamil citizenry that had contributed to the outbreak of the civil war in the first place.

SUMIT GANGULY, a Fellow of the American Academy since 2017, is Professor of Political Science and holds the Tagore Chair in Indian Cultures and Civilizations at Indiana University, Bloomington. He is the author of The Oxford Short Introduction to Indian Foreign Policy (2015), Deadly Impasse: Indo-Pakistani Relations at the Dawn of a New Century (2016), and Ascending India and Its State Capacity (with William Thompson, 2017).
Thestis he Sri Lankan Civil War vividly demonstrates the potential brutality and tenuousness of efforts to end civil wars. ${ }^{1}$ In this case, war termination was the result of an outright military victory. But the conditions that made it possible to end the Sri Lankan Civil War may have been unique: a particular constellation of factors, at systemic, regional, and national levels, proved conducive for the pursuit of an unbridled military campaign that ended the war. At a systemic level, the major powers, including the United States and key European nations, had tired of the conflict. The two major regional powers, the People's Republic of China (PRC) and India, for differing reasons, chose to either support the Sri Lankan regime as it embarked on a massive military onslaught against the rebels or to remain aloof from the conflict. Domestically, the regime that had recently assumed power concluded that it had found an opportune moment to unleash the full might of its military against the insurgents. Consequently, it is unlikely that similar conditions will be present in other contexts.

In May 2009, after two and a half decades of sporadic violent conflict, the Sri Lankan Civil War, which

(C) 2018 by the American Academy of Arts \& Sciences doi:10.1162/DAED_a_00475 
arose from the animosity between the majority Sinhalese and the minority Tamil populations, finally drew to a close. The end of this war was especially bloody, with charges of rampant human rights violations on the part of the two principal parties, the Sri Lankan armed forces and the Liberation Tigers of Tamil Eelam (LTTE). In the final military assault that lasted from January to early May 2009, some seven thousand ethnic Tamils were killed. ${ }^{2}$ But the total number killed in the civil war is a vigorously contested subject. The United Nations puts the death toll between eighty thousand and one hundred thousand. The Sri Lankan government, however, challenges those figures. ${ }^{3}$ Apart from the death toll, following the termination of hostilities, as many as three hundred thousand Tamils who had fled the war zone were interned in overcrowded camps. ${ }^{4}$

This essay will discuss the origins of the Sri Lankan Civil War, briefly examine its international dimensions (including an abortive Indian effort to terminate the war between 1987 and 1989), discuss the third-party negotiations to conclude the conflict, and focus on the politico-military strategy that led to its end. Finally, it will argue that the mode in which the war ended may have damaged the prospects of a lasting peace.

The he origins of the Tamil-Sinhala conflict can be traced back to Sri Lanka's colonial history. During the period of British colonial rule, which extended from 1815 to 1948 , the minority Tamil community seized various opportunities for economic advancement. To that end, significant numbers of the community had availed themselves of a colonial education, primarily because they had limited economic opportunities in the regions in which they were located. The dominant Sinhala community, with marked exceptions, however, had distanced themselves from the British. Not surprisingly, when independence came to Sri Lanka in Sumit 1948 (largely as a consequence of British coGanguly lonial withdrawal from India in 1947), Tamils were disproportionately represented in public services, higher education, journalism, and the legal profession. ${ }^{5}$

The Sinhala elite, who had worked with the British from the early 1930 s to bring about an eventual transfer of power, had paid little heed to the inherently ethnically plural features of the country. When universal adult franchise was extended to all Sri Lankans in 1931 under the Donoughmore Constitution, no provisions were included to guarantee minority rights. Not surprisingly, key members of both the Tamil and Muslim communities had protested the absence of clear-cut provisions for the protection of minority rights. Tamils, unhappy with the constitutional dispensation, boycotted the elections held under the aegis of this constitution. Even the subsequent Soulbury Constitution of 1947, which paved the way to independence, did not include a bill of rights. It did, however, include a clause that prohibited discrimination against any citizen on the basis of ethnicity or religion, but this constitutional provision proved to be rather tenuous. In fact, it laid the foundation for what was soon to emerge as a unitary and majoritarian state. ${ }^{6}$

Worse still, in the aftermath of independence, Sri Lanka's first prime minister, Don Stephen Senanayake, passed legislation that effectively disenfranchised a significant segment of the Tamil community, including the descendants of Tamils who had been brought to Sri Lanka in the nineteenth century as tea and coffee plantation laborers. The passage of this legislation gave the Sinhalese an effective twothirds majority in Parliament, thereby ensuring their dominance. ${ }^{7}$

Senanayake's successor, Solomon West Ridgeway Bandaranaike, also exploited, until his death in 1952, the overrepresentation 
Ending the of Tamils in both the governmental bureauSri Lankan Civil War cracies and the private sector to stoke resentment among the majority community. Among other matters, they argued that since Tamils were disproportionately represented in the field of higher education, they were prone to favor fellow Tamils. Ultimately, they passed the Sinhala Only Act of 1956, which effectively marginalized the Tamil community in every possible sphere, from employment to higher education.

Matters worsened over the next two decades for the Tamil population of the country. One important turning point came in 1971 when the regime of Prime Minister Sirimavo Bandaranaike introduced a system of standardization in university admissions. This procedure stipulated that Sinhala students with lower scores could be granted university admissions. ${ }^{8}$ Not surprisingly, this policy further alienated Tamil youth and contributed to their radicalization. Subsequently, in 1972, the country adopted a new constitution. Under the terms of this constitution, Buddhism was given the foremost status, denigrating other faiths. This decision contributed to a milieu of growing majoritarian sentiment and created permissive conditions for the growth of anti-Tamil commentary in public discourse. ${ }^{9}$

It was against this political backdrop that, in 1976, a young Tamil, Velupillai Prabhakaran, who had witnessed the antiTamil riots of 1958, created the Liberation Tigers of Tamil Eelam as an alternative to the moderate and agitational politics of the Tamil United Liberation Front (TULF). ${ }^{10}$ The LTTE's political goals were ostensibly similar to those of the TULF : like the TULF, it had sought a separate Tamil state. However, unlike the TULF, it was prepared to wage an armed struggle to achieve that goal. In any case, after 1983 , following the passage of a law that required legislators to uphold the territorial integrity of Sri Lanka, the TULF's stated goal became moot. The LTTE, however, remained unalterably committed to the creation of a separate Tamil state. ${ }^{11}$

Prabhakaran had apparently concluded that, after the "standardization" legislation of 1971 and the republican constitution of 1972, the rights of Tamils in the country were now under serious assault. He was hardly alone in embracing this view of minority rights. These sentiments were widely shared among Tamil youth, who Prabhakaran steadily recruited to the cause of a violent revolt against the country's political order. ${ }^{12}$

T he Civil War is frequently divided into four distinct phases, starting in 1983 with the anti-Tamil pogrom in the capital city of Colombo. This first phase culminated with the Indian intervention in the conflict in 1987. The second phase started in 1990 and ended in 1995 with the collapse of the direct talks between the LTTE and the government of President Chandrika Kumaratunga. The third phase, in turn, began in 1995 and ended with the final collapse of the cease-fire agreement in 2006. The fourth and final phase began shortly thereafter and lasted until 2009, when the LTTE was finally defeated.

Even though the origins of the Civil War are widely attributed to the anti-Tamil pogrom that had swept through the capital city of Colombo in July 1983, the catalyst for the conflict had been set in motion somewhat earlier by the killing of four policemen, in 1979, allegedly by the LTTE. Immediately thereafter, the government declared a state of emergency in the province of Jaffna and in two airports near Colombo and, a week later, Parliament passed the Prevention of Terrorism Act, which, though modeled on British legislation, included a number of highly controversial provisions. Among them were the authority to imprison individuals accused of involvement with terror for up to eighteen 
months without a trial and virtual immunity for security forces from prosecution.

But despite the passage of this draconian legislation, matters continued to deteriorate. In mid-July 1983, Sri Lankan security forces killed Charles Anton, the head of the military wing of the LTTE. ${ }^{13}$ Shortly thereafter, in retaliation for his killing, the LTTE ambushed a Sri Lankan military patrol in the northern Sri Lankan province of Jaffna and killed thirteen soldiers. The regime of President Junius Jayewardene chose to bring the bodies of the slain soldiers to Colombo for a mass funeral. This act no doubt inflamed Sinhala sentiments and likely created conducive conditions for a violent reprisal against the Tamil community. However, there is evidence that elements of the regime quickly became complicit in an orchestrated attack on Tamils over the course of the next few days. Reliable reports suggest that as many as two thousand Tamils were killed in the course of a week in Colombo and elsewhere. The police proved to be passive spectators, and there is some evidence that members of the armed forces even participated in the violence. ${ }^{14}$

In the initial days after the pogrom, instead of offering some solace to the aggrieved Tamil community, the regime of President Jayewardene focused on the resentments of the Sinhala community. To no particular surprise, in the wake of the pogrom and the governmental response, more than one hundred thousand Tamils were rendered homeless, and several hundred thousand fled the country to India over the next several years. More to the point, the incidents served as the basis of a substantial recruitment tool for the LTTE. In effect, the origins of the full-blown civil war that came to engulf the country for the next thirty odd years can be traced to the tragic events of July 1983.

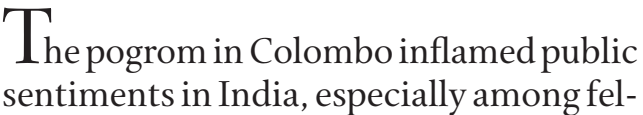

low Tamils in the southern state of Tamil Sumit Nadu. Beyond this domestic issue, which no government in New Delhi could afford to ignore, Prime Minister Indira Gandhi was also concerned about growing American influence within Sri Lanka. India was, for the most part, then at odds with the United States. It had, for reasons of both regional politics as well as its strategic dependence on the Soviet Union, refused to condemn the Soviet invasion and occupation of Afghanistan..$^{15}$

When Indian intelligence agencies reported that the United States could be seeking naval facilities in the eastern port of Trincomalee, New Delhi's anxieties worsened. Keen on asserting India's influence in the domestic politics of Sri Lanka while simultaneously addressing the concerns of Indian Tamils, Prime Minister Gandhi sent a diplomatic mission to Sri Lanka in November 1983. The individual chosen for this task, G. Parthasarathy, was a veteran Indian diplomat and the prime minister's confidante. Parthasarathy was tasked with offering a plan for the devolution of power to elected regional councils in the Northern and Eastern Provinces, where Tamils made up the majority. Various forms of opposition from across the political spectrum, but primarily from the Sinhala parties, and the lack of support from Sri Lankan President Junius Jayewardene, effectively torpedoed this Indian initiative. ${ }^{16}$

In 1983, President Jayewardene gave free rein to the country's armed forces to suppress Tamil militancy. The military crackdown led to significant casualties, including among the civilian population. Concerned about the possible repercussions of this military operation on the electoral politics in Tamil Nadu, Indira Gandhi conveyed her concerns about Tamil civilian casualties. Jayewardene, however, rebuffed her apprehensions. Not one to take kindly to such a response, she granted formal authorization to India's principal counterintelli- 
Ending the gence and counterespionage organization, Sri Lankan the Research and Analysis Wing, to provide
Civil War training and assistance to the various Tamil militant groups. ${ }^{17}$

Over the next several years, the conflict expanded and, in May 1987, the Sri Lankan government launched "Operation Liberation" with the goal of evicting the LTTE from the jungles of northern Sri Lanka. The military onslaught, which was brutal and included the use of barrel bombs by the Sri Lankan air force, contributed to a large-scale flight of Tamil civilians seeking sanctuary in Tamil Nadu. ${ }^{18}$ Faced with this exodus, the government in New Delhi embarked on a humanitarian mission and sent in a flotilla of ships with relief supplies. The Sri Lankan navy, however, intercepted these vessels before they entered Sri Lankan waters. Faced with this rebuff, India's policy-makers resorted to an airdrop of relief supplies. The very next day, after giving the government in Colombo a mere thirtyfive-minute notice, five Indian Antonov An-32 aircraft accompanied by four Mirage fighters airdropped twenty-five tons of relief supplies over Jaffna. ${ }^{19}$

In an attempt to end the Sri Lankan Civil War, while simultaneously appeasing a significant domestic constituency in Tamil Nadu, the home of over sixty million Indian Tamils, Prime Minister Rajiv Gandhi having assumed the office after the assassination of his mother - sought to broker a peace deal between the LTTE, five other smaller Tamil insurgent groups, and the regime of President Jayewardene.

Under the terms of the accord, the Sri Lankan government would, following a referendum, devolve power to the Northern and Eastern Provinces; Tamil would be accorded the status of an official language; the Sri Lankan armed forces would return to the barracks; and the Indian Peace Keeping Force (IPKF) would disarm the rebel groups. ${ }^{20}$

To implement the accord, India sent in a contingent of troops in 1987. The vast major- ity of the various Tamil militant groups acceded to the disarmament requirements and turned in their weaponry within the specified seventy-two hours. What India's political leadership, not to mention its intelligence services, had failed to recognize was that the LTTE was quite unreconciled to the terms of the agreement; its members refused to disarm and quickly turned against the IPKF. As a consequence, the IPKF's mission metamorphosed from a peacekeeping to a peace-enforcement role. Initially, the force scored some notable successes against the LTTE. For example, in November 1987, after the relentless offensive "Operation Pawan," it managed to mostly crush the LTTE in the Jaffna Peninsula. ${ }^{21}$ This, however, did not prove to be a decisive victory. The LTTE successfully regrouped and the IPKF became embroiled in the Sri Lankan Civil War as it sought to defeat the LTTE. After a loss of 1,200 personnel and unable to make much military headway against the LTTE, India withdrew its forces in 1990 at the insistence of the newly elected government of President Ranasinghe Premadasa. ${ }^{22}$ In the waning days of the IPKF's presence in Sri Lanka, the regime started talks with the LTTE. These, however, did not amount to much and ultimately collapsed in June 1990. ${ }^{23}$

\section{$\mathrm{I}_{\mathrm{n}}$} the IPKF from Sri Lanka, the war worsened considerably as neither the Tamil militants nor the Sri Lankan regime appeared interested in a political solution to the conflict. After its military imbroglio, Indian policy-makers also lost interest in seeking a resolution to the conflict and Indian willingness to provide either moral support or material assistance to the Tamils effectively dried up. To curb any efforts on the part of the Tamil Nadu government to renew ties with the LTTE, the Indian national government dismissed the state government and chose to rule the state directly from New Delhi. The LTTE's involvement 
in the assassination of Prime Minister Rajiv Gandhi during the 1991 election campaign further alienated the government in New Delhi from the Tamil cause.

Meanwhile, in Sri Lanka, the LTTE regrouped once again and ratcheted up its military campaign. In 1993, it killed President Ranasinghe Premadasa in a bomb attack. Indeed, it was not until the election of President Chandrika Kumaratunga in August 1994 that some hopes of a negotiated solution to the conflict were rekindled. In January 1995, the Kumaratunga government reached a cease-fire agreement with the LTTE. It also promised that a new set of proposals for the devolution of power would soon be offered. This effort, however, proved to be futile when, in that same year, the LTTE sank a Sri Lankan naval craft. ${ }^{24}$

In response, the Kumaratunga regime launched a military operation against the LTTE bastions in Jaffna in October 1995. This military action, known as "Operation Riviresa" ("rays of sunlight"), was largely a tactical success. However, it left multiple army brigades stranded on the peninsula where they could only be supplied through the sea or air. The LTTE was thus able to quickly isolate the Sri Lankan security forces and overrun them. ${ }^{25}$

For the next several years, war raged in the north and the east of the country. In January 1998, three LTTE suicide bombers attacked the most venerable Buddhist site, the Temple of the Tooth, which, according to devout Buddhists, is the repository of a tooth of the Lord Buddha. Retaliatory raids on Tamil temples and homes followed. ${ }^{26}$ Over the course of the next three years, the LTTE's actions became even more brazen. Two incidents in particular are worth noting. The first was a mostly abortive suicide attack on President Chandrika Kumaratunga in December 1999, though it left her wounded and eventually led to the loss of sight in one eye. ${ }^{27}$ The second episode proved to be costly both in terms of human life and property: an at- Sumit tack on the principal airport in Colombo Ganguly that led to the destruction of nearly half of the fleet of the government-run Sri Lankan Airlines. ${ }^{28}$ In the wake of these vicious attacks, the government of President $\mathrm{Ku}$ maratunga reached out to Norway to mediate a peace process. The Norwegians became involved in 2000 and started discussions both with her regime and the LTTE. ${ }^{29}$

In February 2002, for reasons that are not entirely clear, the LTTE held out the prospect of a cease-fire, which Norwegian mediators managed to broker between the LTTE and the government of Sri Lanka. Under the aegis of this agreement, the road linking Jaffna to the rest of Sri Lanka was opened for the first time in twelve years, passenger flights to Jaffna were resumed, and the government lifted its ban on the LTTE. Furthermore, at least in principle, the LTTE appeared to have dropped its demand for the creation of a separate state..$^{30}$

Altogether, Norway hosted six rounds of talks, but the process collapsed in March 2003. ${ }^{31}$ The talks unraveled largely because the United States had proscribed the LTTE as a terrorist organization. Accordingly, it was not permitted to participate in a preparatory donors' conference in Washington, D.C. Denied this opportunity and concerned about its loss of legitimacy as an international actor, the LTTE announced their unilateral withdrawal from the negotiations in April 2003. ${ }^{32}$ Furthermore, having previously agreed with Colombo to "explore a solution founded on the principle of internal self-determination in areas of historical habitation of the Tamil-speaking peoples, based on a federal structure within a united Sri Lanka," the LTTE now made the resumption of talks conditional on proposals for an interim, independent governance arrangement in the Northern and Eastern Provinces of Sri Lanka. ${ }^{33}$ Subsequent to the termination of these talks, some mediated efforts took place in 2006. However, none 
Ending the of these proved to be especially fruitful. One Sri Lankan Civil War

of them, held in Geneva in February, saw more mutual recriminations rather than meaningful dialogue. Another, scheduled in Oslo in November 2006, saw the LTTE withdraw as it deemed the Sri Lankan negotiating team to be too low-ranking. ${ }^{34}$ The fundamental problem with these negotiations was that the two sides faced an unbridgeable chasm: they had radically different goals. The Sri Lankan government, regardless of regime, wanted to preserve a unitary state, and the LTTE remained committed to the creation of a separate Tamil state. It is worth noting here that, despite the concerted Norwegian efforts to play the role of an honest broker, they ultimately failed. The "treatment regime" for civil wars clearly did not prove up to the task in the Sri Lankan context. 35

Following the collapse of negotiations, the LTTE periodically stepped up its attacks, engaged in a series of successful and unsuccessful political assassinations (including the killing of Tamil foreign minister Lakshman Kadirgamar at his home in Colombo in 2005), and fought off a variety of military operations launched by the Sri Lankan regime.

But then the Sri Lankan Supreme Court ruled that President Kumaratunga's term had ended and in the new presidential election, a hard-line presidential candidate, Mahinda Rajapaksa, was elected to office. Over the course of the next few years, Rajapaksa, in conjunction with his brother, Gotabhaya, who was made the minister of defense, brought about significant changes in military organization and strategy that would ring the eventual death-knell of the LTTE. The government, upon assuming office, had spelled out a two-track "peace process" strategy. At one level, it pursued an aggressive military strategy and, at another, it offered a narrow negotiating agenda on how to best implement an effective cease-fire agreement. ${ }^{36}$
The fundamental difference between the Rajapaksa regime and its predecessors, however, lay in its willingness to grant carte blanche to the military to fight the LTTE to the end, regardless of the economic, human, and diplomatic costs. More specifically, it allowed the Sri Lankan military not to differentiate between the Tamil population and LTTE operatives in rebel-controlled areas. It also permitted anti-LTTE Tamil militants to carry out punitive operations at will. Furthermore, it relied on the state-controlled media to carry out a deft propaganda campaign that grossly exaggerated LTTE casualties in an attempt to bolster both public support for military operations and to boost the morale of its soldiers. Finally, the armed forces, for the first time, carried out a mixed-military strategy combining guerrilla warfare with large-scale artillery assaults supported by air raids. All of these factors created conducive conditions for the termination of the long, drawn-out civil war. ${ }^{37}$

\section{$\mathrm{H}$} ow did this brutal civil war finally come to a close? In considerable part, it stemmed from three sources. At an international level, sympathy for the LTTE had receded in the wake of the September 11 attacks on the United States and global sentiment against the use of terror had welled up. Earlier, in 1996, the U.S. Department of State had designated the LTTE as a "foreign terrorist organization," and, in 2000, the United Kingdom followed suit. These decisions hindered the fund-raising efforts of the organization and hobbled transnational financial transfers.

At a regional level, despite the presence of a substantial Tamil community in India, overt support for the LTTE within the community had waned since the LTTE's involvement in the assassination of Prime Minister Rajiv Gandhi. No national government in New Delhi had any residual sympathy for the organization. 
Finally, when the regime of President Mahinda Rajapaksa chose to start the final military onslaught against the LTTE, it found significant support, especially in the form of substantial amounts of military equipment, including six F7 fighter jets, from the People's Republic of China. The PRC also provided millions of dollars' worth of other military equipment and about $\$ 1$ billion in overall assistance..$^{38}$ All three factors, to varying degrees, played critical roles in ensuring the success of the military campaign against the LTTE.

The critical turning point in ending the civil war came in 2006 when the LTTE, believing that military victory was actually within its grasp, broke off the Norwegian-brokered cease-fire agreement and started what is popularly referred to as the Fourth Eelam War. It was at this point that the Sri Lankan regime made a calculated decision to annihilate the LTTE. To that end, the regime also decided to allocate as much as 3.3 percent of its GDP in 2007 to military spending (up from 2.8 percent in 2006).39 This increase in the military budget also enabled an expansion of the armed forces from 120,000 personnel in 2005 to 300,000 in 2009.

Of course, the LTTE, despite its decision to resume fighting, had been weakened as early as 2004 with the defection of an important leader, Vinayagamoorthy Muralitharan, popularly known as "Colonel Karuna," along with some six thousand LTTE cadres. Because he provided significant tactical intelligence to the Sri Lankan armed forces, his defection was significant militarily. The scale of the defection also suggested to the Sri Lankan government that the popular legitimacy that the LTTE had once enjoyed was now waning.

Battlefield innovation also aided the Sri Lankan armed forces in its mission to crush the LTTE. The army used small, highly trained, mobile groups to infiltrate the LTTE's front lines. These groups attacked high-value targets, provided real-time in- Sumit telligence, and disrupted the LTTE's lines Ganguly of resupply and communications. They were also trained and authorized to call in precision air, artillery, and mortar attacks on LTTE units. ${ }^{40}$ Additionally, the Sri Lankan armed forces launched operations that effectively hunted down and destroyed the LTTE's merchant navy. The deployment of high-speed coastal craft and accompanying tactics also led to the destruction of the LTTE's substantial fleet of maritime suicide vessels. ${ }^{41}$

Military innovation alone, however, cannot explain the battlefield success of the Sri Lankan armed forces. As a number of reputable human rights organizations and news outlets have shown, the military success must also be attributed to the sheer ruthlessness of the tactics that were employed. These tactics demonstrated a flagrant disregard for established norms and conventions governing the use of force. It involved the targeting of civilian areas where LTTE cadres may have taken refuge, the shelling of hospitals where wounded LTTE forces were being treated, and the summary executions of any number of individuals suspected of being LTTE sympathizers. ${ }^{42}$

The LTTE also resorted to brutal military tactics as the war drew to a close. Its leaders deliberately placed civilians in the line of fire, fully expecting the enemy to fire upon them, causing substantial casualties. ${ }^{43}$ They hoped these civilian losses would generate international opprobrium against the government and its security forces. 44

Though the war resulted in the evisceration of the LTTE, the underlying grievances that had precipitated the civil war largely remained unaddressed. Significantly, in the wake of the military victory there was an unbridled sense of majoritarian ethnic triumphalism. Only under significant international pressure did President Rajapaksa appoint a Lessons Learned and Reconciliation Commission in May 2010. The Com- 
Ending the mission released an interim report in SepSri Lankan Civil War tember 2011 and then a final report in November of the same year, both of which came under considerable criticism from global human rights organizations for failing to dispassionately examine allegations of rampant human rights violations during the final phases of the conflict. More to the point, critics underscored a distinct progovernment bias in the final report. ${ }^{45}$ Its shortcomings aside, the report did have a range of practical suggestions for promoting reconciliation. Among these were the need to bring about a reconciliation with the Tamil politicians of the Northern and Eastern Provinces, the election of provincial governments, the resettling of the internally displaced, and suitable Tamil representation in the armed forces and the government. ${ }^{46}$ These recommendations, for the most part, have yet to be implemented.

\section{An extremely determined and single-} minded military effort, facilitated by regional and international conditions, brought an end to the civil war. The military offensive of the Sri Lankan armed forces against the LTTE took place against a particular political backdrop and at a specific historical juncture; it was a moment when global tolerance for any political movement embracing terror was at its lowest ebb in years.

Globally, the United States and the European Union did little to rein in the Sri Lankan government as it embarked on the final stages of its military offensive. Regional states, such as the PRC and Pakistan, actively supported the government. ${ }^{47}$ India, which could have exerted some restraint on the regime, chose not to do so. The military victory of the Sri Lankan armed forces over the LTTE was complete and unequivocal. Obviously, seeking the total destruction of an adversary is one possible strategy for successful civil war termination.

There is little or no question that the LTTE as a viable military force has been effective- ly destroyed. As argued earlier, a combination of international, regional, and domestic forces all converged and facilitated the military defeat of the LTTE. The most significant of these factors, however, was the emergence of a regime in Sri Lanka prepared to brook no opposition in its goal to terminate the protracted conflict. The successful defeat of the LTTE and the concomitant end to the civil war initially generated widespread support and popular enthusiasm for the regime, especially among the Sinhala population of the country.

Despite its popularity in the aftermath of the civil war, the Rajapaksa regime suffered an unexpected defeat in 2015. The common opposition candidate, Maithripala Sirisena, received 51.3 percent of the popular vote. Rajapaksa's ethnic triumphalism had alienated both the Tamil and Muslim minorities and his grasp on the Sinhalese majority had slipped due to charges of widespread corruption and nepotism. ${ }^{48}$

Despite the evisceration of the LTTE and the emergence of a new regime, the perceived injustices of the Tamil community that had set in motion the social and political forces precipitating the civil war, for the most part, remain unaddressed. The new regime, to its credit, established a new Office of National Unity and Reconciliation, which primarily deals with the release of detainees and the return of civilian land that the military had occupied. The office has only been partially successful in addressing these matters. Yet the Prevention of Terrorism Act, which granted the government sweeping powers of arrest and detention, still remains in force, and many who had been incarcerated under its auspices have yet to be released. ${ }^{49}$

Much disaffection with the present Sri Lankan regime of Maithripala Sirisena still pervades the Tamil diaspora communities. ${ }^{50}$ His stated willingness to address the concerns of the diaspora notwithstanding, it is far from certain that he will be able 
to win the necessary domestic political support to effectively pursue such a strategy. Significant social forces and institutional barriers that remain could hobble any steps toward reconciliation. One of these, of course, is the Buddhist clergy, who remain a significant political entity in the country and have little sympathy for their Tamil compatriots. ${ }^{51}$

Another institutional barrier in the pathway toward reconciliation is the uniformed military. Over the course of this protracted civil war and especially during the regime of President Rajapaksa, the military became a vital political actor. The leeway it was granted contributed dramatically to the militarization of the country. Shrinking the role and the scope of the armed forces Sumit will prove to be no easy task. ${ }^{52}$ Under cur- Ganguly rent conditions, it is hard to envisage how a renewed violent Tamil opposition could again emerge. In the absence of concerted efforts to address the human and material costs of the civil war and its antecedents, Sri Lanka is likely to remain a deeply fractured nation riven with profound ethnic cleavages. The shared sense of national identity that Francis Fukuyama deems so necessary to underpin a state's legitimacy does not exist in Sri Lanka. ${ }^{53}$ Instead, significant segments of the Tamil community remain disaffected from the Sinhala-dominated Sri Lankan state.

\section{ENDNOTES}

${ }^{1}$ James D. Fearon, “Civil War \& the Current International System,” Daedalus 146 (4) (Fall 2017).

2 Matthew Weaver and Gethin Chamberlain, "Sri Lanka Declares End to the Tamil Tigers," The Guardian, May 19, 2009.

3 See International Coalition for the Responsibility to Protect, “Crisis in Sri Lanka,” http:// www.responsibilitytoprotect.org/index.php/crises/crisis-in-sri-lanka.

4 Somini Sengupta, "War's End in Sri Lanka: Bloody Family Triumph," The New York Times, May 19, 2009.

5 Stanley J. Tambiah, Sri Lanka: Ethnic Fratricide and the Dismantling of Democracy (Chicago: University of Chicago Press, 1986).

${ }^{6}$ David Little, Sri Lanka: The Invention of Enmity (Washington, D.C.: United States Institute of Peace, 1994), $54-55$.

7 Ibid., 56.

${ }^{8}$ A. Jeyaratnam Wilson, The Break-Up of Sri Lanka: The Tamil-Sinhala Conflict (London: C. Hurst and Company, 1988), 131.

9 Neil DeVotta, "The Liberation Tigers of Tamil Eelam and the Lost Quest for Separatism in Sri Lanka," Asian Survey 49 (6) (2009): 1021-1051.

${ }^{10}$ For a detailed discussion of the LTTE's adoption of a terrorist strategy, see P. Sahadevan, "On Not Becoming a Democrat: The LTTE's Commitment to Armed Struggle," International Studies $32(2)(1995): 249-281$.

${ }^{11}$ Paul Moorcraft, Total Destruction of the Tamil Tigers: The Rare Victory of Sri Lanka's Long War (Barnsley, United Kingdom: Pen and Sword, 2012), 13.

${ }^{12}$ M. R. Narayan Swamy, Tigers of Lanka: From Boys to Guerillas (New Delhi : Konark Publishers, 1995), $49-92$.

13 Thomas A. Marks and Tej Pratap Singh Brar, "Sri Lanka: State Response to the Liberation Tigers of Tamil Eelam as an Illicit Power Structure," in Impunity: Countering Illicit Power in War and 
Ending the Sri Lankan Civil War
Transition, ed. Michelle Hughes and Michael Miklaucic (Washington, D.C. : Center for Complex Operations, National Defense University, 2016).

${ }^{14}$ Charles Haviland, "Remembering Sri Lanka's Black July,” B BC News, July 23, 2013, http:// www.bbc.com/news/world-asia-23402727. See also Marks and Brar, "Sri Lanka."

15 Sumit Ganguly, The Oxford Short Introduction to Indian Foreign Policy (New Delhi : Oxford University Press, 2014).

${ }^{16}$ Much of this discussion has been derived from Rajat Ganguly, Kin State Intervention in Ethnic Conflicts: Lessons from South Asia (New Delhi: Sage, 1998).

17 Harkirat Singh, Intervention in Sri Lanka: The IPKF Experience Retold (New Delhi: Manohar, 2007), 22.

18 Swamy, Tigers of Lanka, 235.

19 Ibid., 236.

${ }^{20}$ Ralph P. Premdas and S. W. R. Samarsinghe, "Sri Lanka's Ethnic Conflict: The Indo-Lanka Peace Accord," Asian Survey 28 (6) (June 1988): 676 - 690.

${ }^{21}$ Dilip Bobb, “A Bloodied Accord,” India Today, November 15, 1987.

${ }^{22}$ Singh, Intervention in Sri Lanka.

${ }^{23}$ Gamini Keerawalla, Post-War Sri Lanka: Is Peace a Hostage of Military Victory? Dilemmas of Reconciliation, Ethnic Cohesion and Peace-Building, Research Paper No. 8 (Colombo: International Center for Ethnic Studies, 2013), 4.

24 John F. Burns, "Rebels Hijack Civilian Ferry in Sri Lanka," The New York Times, August 31, 1995.

${ }^{25}$ Marks and Brar, "Sri Lanka."

26 “Eleven Killed in Truck Bombing at Sri Lanka Buddhist Site,” The New York Times, January 26, 1998.

27 Dexter Filkins and Waruna Karunatilake, "Sri Lankan President Wounded in Suicide Bomber Attack," The Los Angeles Times, December 19, 1999.

${ }^{28}$ Nirupama Subramanian, “LTTE Storms Colombo Airport, Destroys 11 Planes,” The Hindu, July 25, 2001.

29 Gunnar Sørbø, Jonathan Goodhand, Bart Klem, et al., Pawns of Peace: Evaluation of Norwegian Peace Efforts in Sri Lanka, 1997 - 2009 (Oslo : Norwegian Agency for Development Cooperation, 2011), 33-34.

30 The sincerity of this shift is debatable. Sandra Destradi and Johannes Vullers, The Consequences of Failed Mediation in Civil Wars: Assessing the Sri Lankan Case, GIGA Working Papers 202 (Hamburg: German Institute for International and Area Studies, 2012).

${ }^{31}$ Shivshankar Menon, Choices: Inside the Making of India's Foreign Policy (Washington, D.C. : The Brookings Institution Press, 2016), 91.

32 Sørbø et al., Pawns of Peace, 44.

33 Ibid., 41.

34 Destradi and Vullers, The Consequences of Failed Mediation in Civil Wars, 11.

35 Richard Gowan and Stephen John Stedman, “The International Regime for Treating Civil War: 1988-2017," Doedalus 147 (1) (Winter 2018).

${ }^{36}$ Albert Wesley Harris, “War Termination in Sri Lanka," Studies in Sociology of Science 3 (3) (2012): $68-78$.

37 DeVotta, "The Liberation Tigers of Tamil Eelam and the Lost Quest for Separatism in Sri Lanka," 1042.

${ }^{8}$ Peter Popham, “How Beijing Won Sri Lanka’s Civil War,” The Independent, May 22, 2010. 
39 Saroja Selvanathan and Eliyathamby A. Selvanathan, "Defence Expenditures and Economic Sumit Growth : A Case Study of Sri Lanka Using Causal Analysis," International Journal of Development Ganguly Studies 4 (2) (2014): $69-76$.

40 Many of these operational details have been drawn from Peter Layton, "How Sri Lanka Won the War," The Diplomat, April 9, 2015, http://thediplomat.com/2015/o4/how-sri-lanka-won -the-war/.

${ }^{41}$ Marks and Brar, "Sri Lanka."

42 Harris, "War Termination in Sri Lanka," 73.

43 Jayadeva Uyangoda, “Sri Lanka in 2009: From Civil War to Political Uncertainties," Asian Survey $50(1)(2010): 104$

44 Harris, "War Termination in Sri Lanka," 72.

45 Amnesty International, When Will They Get Justice? Failures of Sri Lanka's Lessons Learned and Reconciliation Commission (London: Amnesty International, 2011).

46 Alyssa Ayres, “Sri Lanka’s Victory for Democracy,” Forbes, January 9, 2015, http://www .forbes.com/sites/alyssaayres/2015/01/09/sri-lankas-victory-for-democracy/\#55a940a02572.

47 Popham, "How Beijing Won Sri Lanka’s Civil War."

${ }^{48}$ Chandra R. De Silva, "Sri Lanka in 2015: A Year of Change," Asian Survey 56 (1) (2016): 199 - 203.

49 Ibid., 202.

50 "Sri Lankan Govt Keen to Reconcile with Tamil Diaspora Including Extremist Groups," Daily News and Analysis, June 13, 2015.

${ }^{51}$ Stanley Jeyaraja Tambiah, Buddhism Betrayed? Religion, Politics and Violence in Sri Lanka (Chicago : University of Chicago Press, 1992).

52 Taylor Hibbert, “Militarization in Sri Lanka Continues,” The Diplomat, February 9, 2016, http :// thediplomat.com/2016/o2/militarization-in-sri-lanka-continues/.

53 Francis Fukuyama, “The Last English Civil War,” Daedalus 147 (1) (Winter 2018). 